\author{
Martin HOMZA \\ Comenius University in Bratislava \\ martin.homza@uniba.sk
}

\title{
SCLAVINIA - INTERMARIUM? \\ OR ABOUT ONE MISSING ROMAN PROVINCE
}

\author{
MERIDIONAL VECTOR IN EAST-CENTRAL EUROPE. \\ AN ESSAY ON STRENGTHS AND WEAKNESSES \\ OF TWO GOOD NEIGHBORS
}

ABSTRACT If someone had sighed at the beginning of the 19th century that a unified German state would be formed in some time and Italy would able to unite itself, that one would certainly concerned to be a fool. Yet these ideas were realized in full around the year 1870. Few, however, realized that the 19th century by the accomplishing those political goals Europe came to a state that reminds the dearest dreams of the ideologists of the year 1000, who put forward a concept of European political arrangement built as an imaginary Tetrarchy consisting of 4 equal provinces Galia, Germania, Roma and Sclavinia. As it is clear, Sclavinia of these provinces, is still missing. The presented article attempts to give an overview of the implementation of the „Sclavinia project” with the assignment of its other names, such as Intermarium, throughout history. Martin Homza demonstrates this on mutual Slovak-Polish relations, which considers the basic axis of this possible construction. Methodologically, these relations divids into 4 subcategories according to the strength and weakness of their bearers: Relation: Strong: Strong; Weak: weak; Weak: Strong and Strong: Weak.

Key words: Sclavinia, Intermarium, the Kingdoms of Hungary and Poland, Nitra Principatity, the Slovaks, the Slavs, the Hungarians, the Polish 
Slovak-Polish relations form a part of broader North-to-South/South-to-North $\checkmark$ continental networks that connect the Balkans and the Italian peninsula with the Baltics. In the region, the Carpathians present a major natural barrier that has determined the shape of these relations. Territories beyond the mountains are part of the Northern European flatlands. From the other side, the range with its characteristic curve helps to delimit the Danube river basin. Throughout history, the Carpathians have thus played a role of borders - natural, historical, cultural, and political - between every polity that emerged in the old Pannonia, and its neighbor to the north. As it happened, the first relevant partner beyond the Carpathians was to be Poland. In the south - after the Roman Empire had retreated from the space around the Danube - the power vacuum was filled by relatively short-living empires of Goths and Huns, and then there appeared the Avar Khaganate, Svätopluk's Sclavinia, the Hungarian kingdom for a thousand years, Czecho-Slovakia (Slovakia), and Hungary. Throughout their history, both political spaces tended to unite their forces in response to political pressure that originated in the West - i.e. in all historically known forms of German statehood. Influence from the East was perceived as less profound, yet it gradually did gain significance (until 1989). It originally extended from the Byzantine, later from the Ottoman Empire, and since the $18^{\text {th }}$ century from all historically known forms of Russian statehood (including the Soviet Union). From a historical perspective, the Hungarian and Polish kingdoms seem to represent the most enduring political formations on both sides of the Carpathians. One could even say that it was the relations between these two countries that formed the basis for East-Central European politics along the north-south axis. The situation might seem clear at first sight. However, the topic of international relations is complicated to such a degree that it becomes necessary to define criteria, according to which the main issues in the mutual contacts could be synthesized in the form of easily comprehensible models.

On the basis of the strength - or weakness - of political structures on either side of the Carpathian mountain range, the history of Polish-Hungarian (Slovak) relations can be thus divided into four basic paradigms. Three of them are conveniently summarized in selected passages in medieval narrative sources, which bestows that kind of validity upon them that transcends the limitations of a specific period. The fourth one could only be observed in recent years, though. That is one of the reasons why it will be analysed first. It needs to be added, however, that a given pattern of mutual connections cannot be neatly identified only with one historical epoch. Exactly the opposite seems to be the case, since each model can be found - theoretically, at least -in any historical period. In every modeled paradigm of relations, there are, quite naturally, also elements that either transcend or update it. On the basis of comparison of strength of the polities around the Carpathians, the following four patterns can be identified: 1) weak : weak; 2) strong : strong; 3) weak : strong; 4) strong: weak. 


\section{Ad 1) Weak : Weak - or the current situation}

The situation when neither Poland, nor the states in the Danube basin wield enough political or economic power to resist its neighbors emerged at the end of World War II. At that point, namely, the region of East-Central Europe ${ }^{1}$ ended up in the Soviet sphere of influence. This situation repeats itself also nowadays, only in the opposite direction. After a transient period of a political and economic independence that followed the regime change of 1989 , a new structure of dependencies has been developing. So far, the process has lead to an ever deeper integration of the region - economically, constitutionally, and culturally - with its closest neighbor to the West, Germany. One could speak of the European Union (thereinafter EU) as such, but it is important to stress the German factor here, since French (Gallia) interests are much more oriented towards the Mediterranean. It is precisely Germany (Germania), however, that has - also historically - placed higher value on cultivation of intense, and multifaceted relations with the West Slavs, Hungarians, Croats, and other nations that nowadays tend to be placed under the common heading of East-Central Europe.

If there should be found a parallel to the current situation in the history of the region, one would need to go back to the era of military campaigns led by Charlemagne at the turn of the $8^{\text {th }}$ and $9^{\text {th }}$ centuries. Then, the system of pax Avarica that had shaped the region for the previous 250 years crumbled when confronted with the Frankish military power. ${ }^{2}$ As it happens, the modern EU seems to resemble Charlemagne's empire at least geographically, thanks to the historically unprecedented overcoming of mutual Franco-German (West and East Frankish, if you will, or Gallia et Germania) antagonisms, or one could say thanks to the fact that the Germans have accepted to patiently and meekly pay the price for peace (tributum pacis) to the French. ${ }^{3}$ When Bronisław Geremek, then the Foreign Minister of Poland, was awarded an honorary Golden Great Medal by Comenius University in March 2000, he quibbled that EU truly is the empire of Charlemagne, with the addition of the originally provincial territories of Britain, Scandinavia, Iberia... The strategic aim of such a project needs to be the same, too - i.e. re-creation of the Roman Empire. Charlemagne managed to create a system of stability, Pax Francorum (Peace of the Franks), along his empire's eastern borders that lasted for over a hundred years (796-907). A network of small Slavic principalities that emerged after the fall of the Avars did last, however, only for a couple of decades. It began to disintegrate in the 850 s, after the division of the Carolingian empire among Charlemagne's grandsons (Verdun, 843). The process eventually led to the formation of Great Moravia, which was the first politically relevant power of the

1 For a discussion of the term see for example Central Europe Between East and West, J. Kłoczowski (ed.), Lublin 2005, passim.

2 The techniques that were used by the Empire to integrate Carinthia, Duchy of Pannonia, and adjacent Slavic territories after 796 are analyzed in Ch.R. Bowlus, Franks, Moravians, Magyars: The Struggle for the Middle Danube, Philadelphia 1995.

3 With the pending Brexit deadline, the United Kingdom is currently in search of a new platform on which its relations with the EU could be based. 
region. ${ }^{4}$ After its demise, it was the Hungarian kingdom that preserved its Central-European political legacy - especially in cooperation with Poland - against the most common allies of the German kingdom in the area, the Eastern March (Duchy of Austria) and the Bohemian duchy. After the incorporation of the Kingdom of Hungary into the Habsburg Monarchy (in the aftermath of 1526), rulers of the House of Habsburg appropriated the conception of the Central-European policy. This situation endured until the events of 1866, when the Austrian Empire lost the battle of Hradec Králové (Königgrätz). The subsequent peace treaty of Mikulov (Nikolsburg) indicated the beginning of a gradual retreat of the Habsburg empire into the shadow of its more powerful neighbor, Prussia. The political and ideological concept that the subsequent shift towards Prussian hegemony (1870-1918) in this part of the old continent was expressed in the form of the political and ideological concept of Mitteleuropa. ${ }^{5}$ One of the negative results of the German domination in the region was World War I.

\section{Ad 2) Strong : Strong - or Poland as a subject of the Apostolic See, not the Emperor...}

In the famous Preface to the Ksiega elblaska (The Book of Elbing), the oldest Polish legal collection from the beginning of the $13^{\text {th }}$ century, there is a remark that the Germans had a neighbor whose legal system had been created by its own sages and therefore it had not become subject of any other political power. It was the Poles, obviously, who was meant as this neighbor nation. On the other hand, Roman Empire as represented by the medieval German monarchy was understood as the "other power". The notion is expressed explicitly in the very first paragraph of the legal code: "To those who want to learn the Polish law may it be known that Poles, since the acceptance of the Christian faith, have been subjects of the Apostolic See in Rome, not of the Emperor..." For the first time, this stance found expression in the bull Industriae tuae in 888 that Pope John VIII addressed to Svätopluk, when taking his empire under papal protection. ${ }^{8}$ In a sense, St. Stephen of Hungary was an heir to Svätopluk. In the Hungarian-Polish Chronicle - similarly as Svätopluk before him - Stephen dedicates his empire as a fief to the See of Saint Peter. ' Legally it could have meant only one thing, namely

4 D. Třeštík, Vznik Velké Moravy, Praha 2010.

5 For the understanding of the concept, see the following map at $<$ https://upload.wikimedia.org/wiki pedia/commons/c/c0/Grossgliederung_Europas-en.svg>, 22 October 2018.

6 Najstarszy zwód prawa polskiego: Das äleste Gewohnheitsrechtsbuch, ed. and transl. by J. Matuszewski, J. Matuszewski, Łódź 1995, 167 pp. (here pp. 31 and 32, paragraph 1).

7 If not specified otherwise (in absence of a scholarly edition with an appropriate English rendering of the source), all the translations of the primary sources in the text have been made only for the purposes of the present study.

8 Codex diplomaticus et epistolaris Slovaciae (thereafter CDSL), R. Marsina (ed.), vol. 1, Bratislava, 1974, No. 39, p. 33.

9 See: Uhorsko-pol'ká kronika: Nedocenený prameň k dejinám strednej Európy, ed., trans. a comment. by M. Homza, J. Balegová, Bratislava 2009, pp. 146-147. 
that the space to the east of the German (Imperial) border was politically independent from the Empire. The importance of the subordination to Rome, originally declared only formally (e.g. Mieszko I in Dagome iudex), increased during the struggle between papacy and the Empire. Pope Gregory VII (1073 - 1085) managed to form a wide, anti-imperial alliance that consisted of various Central European principalities, ranging from Croatia in the south through Hungary to Poland in the north. It is no coincidence, then, that Pope Gregory reprimanded the Hungarian king Salomon in 1075 for having given his kingdom, formerly subject to Rome, as a fief to the German king. ${ }^{10}$

Patronage over East-Central Europe was thus assumed by the Holy See. Similar aims could be observed also later. From the end of the $12^{\text {th }}$ century onwards, the popes supported members of the Arpad dynasty in their Polish, Galician, and Balkan political enterprises up until the times of the unworthy Ladislas IV the Cuman (1272-1290). Likewise, Papacy showed support to the Anjou kings (1308-1385), successors of the Arpadians on the Hungarian throne. Charles Robert of Anjou took the initiative to organize a meeting of three royals, the kings of Bohemia, Poland and Hungary at the Hungarian castle of Visegrád ${ }^{11}$ that was - among other things - aimed against the growing political and economic importance of the nearby Vienna. The powerful center between the Baltic and the Adriatic was united (1370-1382) under his son, Louis the Great, again with papal approval. The continuity of the trend can be observed in the politics of the Jagiellonians as well (Jagiełlo married Hedwig, the daughter of Louis the Great, and the later saint, in 1386), especially when they managed to assume both the Hungarian and Bohemian thrones. After them, the Habsburgs became the most powerful representatives of East-Central Europe. Both their domestic and foreign policies were built on cooperation with the descendants of St. Peter in Rome. The Papacy's tacit patronage over the region lasted also during the pontificate of John Paul II, and it is still manifest today. Without depriving the act of its sacral dimension, the canonization of the Three Martyrs of Košice in that same city (i.e. on the Slovak territory) by Pope John Paul II in 1994 could be interpreted also as another political act in a longer Central European tradition. It is no coincidence that one of the martyrs was a Croat, one a Hungarian and the last one a Pole.

There was only one moment in history, actually, when the imperial and papal policies towards the region were in agreement. In the times of Emperor Otto III and Pope Sylvester II, the concept of Sclavinia, the fourth province of Latin Christianity (together with Gallia, Roma, and Germania) prepared the common ground for both powers. The chief proponent of the whole initiative was St. Adalbert (Vojtech). It seems, however, that his ideas were not that new in the political landscape of Europe. How else could one interpret the great decade of Svätopluk I, who - by conquering Pannonia in 884 - managed to unite large parts of modern Germany, Poland, Rus', Bohemia

10 Details of the political struggle are analyzed in: M. Homza, "14. marec roku 1074 a jeho dôsledky na vývoj Nitrianskeho kniežatstva”, in L. Róbert (ed.), Slovenské územie, Martin 2017, pp. 45-65.

11 See the representative, commented edition of the documents pertaining to the meeting in: Visegrád 1335, G. Rácz (ed.), Bratislava 2009. 
and Moravia, Slovakia, Romania and Hungary? Pope Stephen V addressed him, quite logically, as Rex Sclavorum, i.e. King of the Slavs. ${ }^{12}$ And let us once again paraphrase an observation by Geremek, made only as if incidentally: how else could one interpret the summits of presidents of Central European countries that took place at the tomb of St. Adalbert in Gniezno in 1997, and then again in 2000? It was Boleslas (Bolesław) the Brave who was designated as the future ruler of Sclavinia around the year 1000. His kingdom was supposed to consist of an archbishopric and seven bishoprics. The so-called Gallus Anonymus, a Polish chronicler from the beginning of the $12^{\text {th }}$ century, described the extent of the monarchy as follows:

So the Slavonian land is divided in the north into parts by or made up of these regions, and it runs from the Sarmatians, who are also known as Gets, to Denmark and Saxony, and from Thrace through Hungary, which in past times was occupied by the Huns (who are also called Hungarians), and passing down through Carinthia it ends at Bavaria. Toward the south, starting from Epirus on the Mediterranean Sea it includes Dalmatia, Croatia, and Istria, and ends on shores of the Adriatic Sea, where Venice and Aquileia stand, separating it from Italy. ${ }^{13}$

This concept, depending on whether it involved the ethnic (Slavic) or state-political element, was later transformed into: a) the idea of a West-Slavic confederation that would involve above all Poland, Bohemia and Moravia, and Slovakia with Carpathian Ruthenia; and b) the concept of Central European federation (with Hungary, and Slovakia as separate units), but under Polish leadership. Among the supporters of the former during WWII one could mention the Polish general Władysław Sikorski, the Slovak politicians Karol Sidor and Štefan Osuský, and the Czech statesman Edvard Beneš, with the caveat that he withdrew his support after the Czechoslovak-Soviet agreement from 1943. Nowadays, the idea of a West-Slavic confederation has witnessed its renaissance, as attested by the inaugural speech of the current Polish president, Andrzej Duda, from 6 August 2015, or by the summit (archaically congress, zjazd) of 12 countries (poetically Three seas, abbreviation BABS, i.e. the Baltic, the Adriatic, and the Black Sea) in Dubrovnik on 25 August 2015. The origins of the second idea, i.e.

12 On the role of continuity of the concept of Slavic kingdom and archbishopric for the origins of the Hungarian and Polish kingdoms, see: M. Homza, "La Grande Moravia tra Oriente e Occidente", in E. Hrabovec, P. Piatti, R. Tolomeo (eds.), I Santi Cirillo e Metodio e la loro ereditá religiosa e culturale ponte tra Oriente e Occidente. Raccolta di studi in occasione del $1150^{\circ}$ anniversario della missione dei santi Cirillo e Metodio nella Grande Moravia (863-2013), Città del Vaticano 2015, pp. 25-35; and N. Malinovská, “«Regnum Sclavorum» Svjatopolka kak istočnik srednevekovych slavjanskich koncepcii Sklavinii”, Studia Slavica et Balcanica Petropolitana, vol. 21, no. 1 (2017), pp. 21-38.

13 Original text in: Galli Anonymi Cronicae et Gesta Ducum sive Principum Polonorum, in C. Maleciński (ed.), Monumenta Poloniae Historica: Nova series, vol. 2 (MPH NS 2), Kraków 1952, pp. 7-8: „Igitur Terra Sclauonica ad aquilonem hiis regionibus suis partialiter divisis sive constitutivis existens, a Sarmaticis, qui et Gete vocantur, in Daciam et Saxoniam terminatur, a Tracia autem per Ungariam (ab) Hunis, qui et Ungari dicuntur, qoundam occupatam, descendo per Carinthiam in Bauariam diffinitur; ad Austrum vero iuxta mare Mediterraneum ab Epyro derivando per Dalmatiam, Crouaciam et Hystriam finibus maris Adriatici terminata, ubi Venetia et Aquileia consistit, ab Hytalia sequestratur." The English translation used here comes from Gesta Principis Polonorum: The Deeds of the Princes of the Poles, ed. and trans. by P.W. Knoll, F. Schaer, Budapest 2003, p. 15. 
a Central European federation with Poland as its leader, are to be found among the Polish exiles in Paris, grouped around Hôtel Lambert and Prince Adam Czartoryski. Shortly before the Munich agreement, Milan Hodža, the foreign minister of Czechoslovakia, presented a similar plan. However, there was neither time, nor support for its implementation. Cooperation within the framework of the Visegrad group is nowadays perhaps its closest analogy.

The historical rupture that temporarily weakened the position of Hungary as the dominant force between the Carpathians and the Danube was the Battle at Mohács (Moháč) in 1526. The Hungarian defeat was followed by Ottoman dominance over most of Hungary for the next 150 years, with the Habsburgs ascending to the throne in one part of the country (known also as Royal Hungary), and with the separation of the remaining part, Transylvania, as a vassal principality of the Ottoman sultans. The situation consolidated only in the latter part of the $18^{\text {th }}$ century, during the reigns of Maria Theresa and Joseph II, when the borders of Hungary definitely stabilized on the Sava and the lower Danube. ${ }^{14}$ At that time, the focus of Polish politics changed as well. It shifted eastwards into the region of Right-Bank Ukraine. There, Poland played the role of a powerful arm of Latin Papacy - following the tradition of previous expansions of Svätopluk I (Sventibald), Boleslas I the Brave and Boleslas II, as well as the Hungarian kings from the Arpad and Anjou dynasties - against the Orthodoxy and Ottoman Islam. Poland did it in its own way, though. The unofficial ideology of this strange state referred to as the Pierwsza Rzeczpospolita Polska (the Polish-Lithuanian Commonwealth), a 'Republic of Nobles' with the king as its head (spanning over the former duchies of Eastern Poland and the Grand Duchy of Lithuania), was nomadic Sarmatism. (By the way, it should be noted that - to an extent - Polish Sarmatism resembled the ideology of the Hungarian nobility that was formulated for the first time by Simon of Kéza, a Hungarian chronicler from the last third of the $13^{\text {th }}$ century. On the basis of the theory, the myth of nomadic Hunno-Atillic origin was emphasized, regardless of the ethnic background of an individual member of the nobility. $)^{15}$ Polish nobility came to express their perceived uniqueness also through physical appearance - by shaving their heads à la Turk as well as by following Istanbul fashion trends. Poland found its counterpart in all these aspects on the other side of the Carpathians, in the Transylvanian principality. The causes of the similarity can already be found in the intermarriages of the Polish Jagiellonians with the Hungarian Zápolyas (se Zápole) - John and his son, John Sigismund, both married Polish princesses. The connection worked also the opposite way: the Polish King Sigismund the Old married Barbara, the daughter of Stephen Zápolya. Later in the $16^{\text {th }}$ century, the Transylvanian prince Stephen Báthory even ascended to the Polish throne (1576-1586). The famous Rzeczpospolita,

14 After a century and a half of the Ottoman occupation, Hungarian kingdom again reached its medieval territorial extent already at the beginning of the $18^{\text {th }}$ century, after the peace treaties of Karlowitz (Sremski Karlovci) in 1699 and Passarowitz (Požarevac) in 1718.

15 J. Szücs, "Theoretical Elements in Master Simon of Kéza’s Gesta Hungarorum (1282-1285)", in Simon of Kéza, The Deeds of the Hungarians, ed. László Veszprémy, trans. F. Schaer, Budapest 1999, pp. XXIX-CII. 
an example of nobiliary democracy, with its notorious liberum veto that could mean the halt to the whole state mechanism even when used by an insignificant member of the small gentry from the remotest village, dissolved itself by its own decree in 1772 . Already three years before that, the Imperial border commission had begun to monitor the land around Nowy Targ and Stary Sącz (nowadays in Poland) in order to attach the so-called Beskidy District to the Hungarian counties of Spiš and Šariš. The border was supposed to lie somewhere near Myślenice. Later I could firsthand observe the material remnants of the new political power taking initiative in the region at that time, by building roads and border stations, as it is quite often the case in such situations. The whole undertaking came to be known under the name "Török's action", and the planned Beskidy District is also depicted on a corresponding map from the period. ${ }^{16}$ The establishment of a new Austrian province, the Kingdom of Galicia, eventually led to Galicia becoming part of the Habsburg Monarchy, but as a component of Austrian crown lands rather than of the Crown of St. Stephen.

Whatever the details, the model strong: strong that emerged around the year 1000 on the shambles of Svätopluk's Regnum Sclavorum eventually became a determinant of the definition of East-Central Latin Europe. Its most important result was the halting of the eastward expansion of the re-crated Roman (German) Empire.

\section{Ad 3) Weak : Strong, or Poland quartered as the body of St. Stanislaus}

The disintegration of Poland in the $18^{\text {th }}$ century was not the first. The Life of St. Stanislaus, bishop of Cracow, a martyr and a fighter against the secular power as well as the first saint of Polish origin, draws interesting analogies In this regard. As Polish king Boleslas II ordered the saint's body to be quartered, so, too, the Polish kingdom would disintegrate. But as the parts of the bishop's body miraculously came together to form one whole again, so would do the parts of the divided kingdom. ${ }^{17}$ Poland has experienced such a situation already a couple of times. The best known are the following three examples. Firstly, in the period after 1138 the country was divided into more principalities on the basis of the testament of Duke Boleslas III the Wrymouth. These units subsequently fought for dominance within the formally still existing Polish kingdom until Vladislas (Władysław) I the Elbow-high (1306-1333) managed to dominate the larger part of the realm. ${ }^{18}$ The second case was the Partitions of Poland of 1772-1795, which resulted Poland losing its statehood until 1918. The third disintegration of the country dates back to 1939, when it was divided between the Third Reich and the Soviet Union after their successful military campaigns. Only five years later, however, Poland rose from the ashes again, only to end up in the Soviet sphere of influence, together with

16 See the map no. 9 in: D. Duchoňová, M. Duchoň, “Spiš v rokoch 1711-1769”, in M. Homza, S.A. Sroka (eds.), Historia Scepusii, vol. 2: Dejiny Spiša od roku 1526 do roku 1918, Bratislava-Kraków 2016, p. 347.

17 See: S. Kuzmová, Preaching Saint Stanislaus: Medieval Sermons on Saint Stanislaus of Cracow: His Image and Cult, Warszawa 2012.

18 S. Szczur, Historia Polski: Średniowiecze, Kraków 2002, 676 pp. 
other countries of the region. In all these cases, the power balance in mutual relationships favored Poland's southern neighbor.

In the first case, the Hungarian efforts to gain suzerainty over Galicia and Lodomeria (Vladimir), Poland's eastern neighbors and westernmost duchies of Kievan Rus', significantly intensified. Between the years 1140 and 1235, there were more than 20 Hungarian military expeditions heading in this direction, even though the area remained the sphere of Polish interest. The title rex Galitiae et Lodomerie (king of Galicia and Lodomeria) thus made its way into the titulature of the Hungarian kings from the times of Andrew II (1205-1235) onwards. ${ }^{19}$ As a historical curiosity, one might observe that the Polish Queen Hedwig of Anjou (1384-1386), ${ }^{20}$ a Hungarian princess and a later saint (since 1997), incorporated the contested territory of Galicia to Poland by military action. The focus of Polish politics had thus shifted more to the East. History only repeated itself when Emperor Joseph II - or already his mother Maria Theresa- annexed the part of Poland known as Lesser Poland to their realm, and gave it the name of Galicia (Galizien), in tune with historical tradition. The strategic interests of the Poland's southern neighbor were always aimed at gaining control over the northern slopes of the Carpathians. That would enable Hungary to achieve hegemony in the region as well as to control the mountain passes and thus to exert power over the trade routes connecting the Carpathian region with Russia. The first ruler who most probably pursued this objective was Svätopluk I (after 874), and the last one in the row was Francis Joseph I (1848-1916).

Hungarian interests beyond the Carpathians, however, were never meant to incite open political confrontation with Poland, perhaps with the exception of Török's action. The focus of the Hungarians laid more to the east, in Galicia and Lodomeria. This could have been hardly caused by the lack of interest on the Hungarian side. Rather, it was the result of a peace agreement between Poland and Hungary that was described for the first time by the Hungarian-Polish Chronicle. A remark can be found there that when Poles did not receive the royal crown from the Pope around 1001, they occupied the territory of Slovakia. However, Pope Sylvester II coerced the Poles to conclude the apostolic peace with Hungary. ${ }^{21}$ The agreement came to be known as the peace of St. Adalbert and St. Stephen, mainly thanks to the mid- $13^{\text {th }}$ century Polish chronicler Wincenty Kadłubek:

...it renews itself according to the stipulations of the saints, namely of the holy king Stephen and of the holiest patron of Poland Vojtech (Adalbert), in order to maintain friendship between both realms, to jointly fight against the enemies of both of them: in good times to jointly reap benefits, and in poor times to hurry up to the aid of each other. ${ }^{22}$

19 M. Homza, "Včasnostredoveké dejiny Spiša", in M. Homza, S.A. Sroka (eds.), Historia Scepusii, vol. 1: Dejiny Spiša do roku 1526, Bratislava-Kraków 2009, pp. 146-148.

20 J. Wyrozumski, Królowa Jadwiga: Między epoką piastowską i jagiellońską, Kraków 1997, p. 142.

21 M. Homza, J. Balegová (ed., trans. and comment.), Uhorsko-pol'ská kronika, Bratislava 2009, pp. 150-155 .

22 MPH NS 11, ed. M. Plezia, Kraków 1994, pp. 165-166. English translation of the passage made only for the purposes of this essay. 
It has come to represent the most stable and lasting peace among any European countries or nations ever. Poland, ripped and bleeding, played a balancing role in the process of constituting modern Slovak politics. When Ján Kollár in his poem Slávy deera imagined the future of Slavic Europe, he did not find the place for Poland in it. On the other hand, the subsequent Štúr generation understood the Polish question. There was hardly any other contemporary Slavic national movement other than Ludovít Štúr's circle that would have showed more sympathy towards the Polish exiles and their conviction that the freer Poland would be, the more freedom all other nations under the suzerainty of Vienna would enjoy. However, when the youngsters grew older and became more pragmatic, at the end of the 1860s, they stiffened in their orientation towards Russia. Rather differently than the so-called "Old Slovak school", a more progressive group, the "New Slovak school", centered in Buda and Pest under the leadership of Ján Pallárik, used the Polish card again. After the Ausgleich between Hungarians and Austrians, however, this progressive line of Slovak politics witnessed a gradual decline in importance. When Czecho-Slovakia ${ }^{23}$ was established in 1918, a significant faction of the most powerful player on the Slovak political scene, Slovak People's Party, began to orient themselves towards Poland, despite the fact that the official foreign policy of Czechoslovakia (Czechia) was rather anti-Polish.

\section{Ad 4) Strong: Weak, or ...confidentes in stulta potentia sua}

Some medieval chroniclers managed to incorporate such sentences into their texts founding charters of future nations, as it were - that would gain formative character for these nations' histories. For example, the author of Hungarian-Polish Chronicle, writing at some point in the $13^{\text {th }}$ century, described the Poles as confidentes in stulta potential sua. ${ }^{24}$ This can be translated to mean that Poles tend to rely too much on their foolish power. Apart from the insinuated reproach, the sentence may be interpreted also as an evaluation. From this point of view, the author might have felt weaker when compared to the might of the Poles and Poland at his time, perhaps even smaller and a bit dependent on them. Such an interpretation would serve as a basis for the chronological dating of the remark. Since Poland entered the period of partition after 1138, it could hardly be argued that it would have posed a significant threat to Hungary and, thus, any appraising of its strength would have felt misplaced as well. Therefore, the remark should be dated to an earlier period. There indeed was a fitting time for such an expression, namely, beginning around 998, when the tribe of the Polans took Cracow from the Czechs (as already described by Gerard Labuda ${ }^{25}$ ) and the new power entered

23 The term "Czecho-Slovakia" is used by the Treaty of Saint-Germain-en-Laye (1919).

24 M. Homza, J. Balegová (ed., trans. and comment.), Uhorsko-pol'ská kronika, pp. 142-143.

25 G. Labuda, "Ze stosunków polsko-węgierskich w drugiej połowie X wieku”, in J. Bardach et al. (eds.), Europa - Stowiańszczyzna - Polska: Studia ku uczczeniu profesora Kazimierza Tynieckiego, Poznań 1970, pp. 71-88. 
the political stage in the Danube basin. It was precisely the conquered city that almost always played a role of both the originator as well as a mediator in relation to the history of old Hungary and Slovakia. Boleslas I the Brave (992-1025), the oldest son of duke Mieszko, started his expansion there, too. "[W]as it not he who time and again defeated the Hungarians in battle and made himself master of all their lands as far as the Danube?" asked Gallus Anonymus. ${ }^{26}$ The phrase "as far as the Danube" is to be understood here as meaning the southern border of the Duchy of Nitra that had already been ruled by at least the second generation of the local Arpadians. What is meant is the modern territory of Slovakia that the anonymous author of the Hungarian-Polish Chronicle described as follows: from Esztergom, through Vacov (Hung. Vác), under the Matra (Hung. Mátra) Mountains to Jáger (Hung. Eger), from there to the confluence of the Tisa (Hung. Tisza) and the Topla rivers and, finally, upstream of the latter up to the castle Salis (Galis), nowadays Solivar near Prešov. ${ }^{27}$ It was not, however, the only time in the first century of the existence of both neighbors that Poland took initiative in the lands south of the Carpathians. Boleslas (Bolesław) II the Generous, the grandson of Boleslas (Bolesław) I, entered Hungarian politics in the period 1057-1079 along the lines of his famous predecessor and namesake. In the internal struggle for the Hungarian crown, Boleslas had a dynastic stake. He supported his own nephews, Geza and Ladislas I, sons of Bela I and his Polish wife, Boleslas' sister. ${ }^{28}$ They had reigned in tertia pars regni, namely in the one third of the kingdom that corresponded to the duchies of Nitra and Bihor. As usual, high European politics was involved, too, this time in the form of a conflict between Empire and Papacy. History repeated itself later. For the third time, the Polish duke, Boleslas III the Wrymouth (1102-1138) gave his support to another claimant to the Hungarian throne in the years 1132-1134. His protégé was Boris Kolomanovich, the son of the Hungarian king Coloman the Bookish (1095-1114) and his repudiated wife, the Russian princess Euphemia. However, Boleslas III wielded less power than his predecessors. Moreover, the Duchy of Nitra had formally ceased to exist after the reign of Ladislas I. As a result, the whole operation collapsed at the battle of the Slaná River in 1132 where the Polish-Kievan coalition did not receive much awaited support of the local Pannonians (Chronicle of Master Wincenty called Kadtubek). ${ }^{29}$

A couple of previously mentioned successful Polish interventions in Hungarian matters, however, proved to be a justification good enough for the author of the Hungarian-Polish Chronicle to express himself as stated above. Despite the involvement in the territory of the Duchy of Nitra, Polish political strategies did not really produce any positive results. The rulers of Nitra turned their backs on their Polish

26 MPH NS 2, p. 16: „Numquid non ipse Vngaros frequencius in certamine superavit, totumque terram eorum usque Danubium suo dominio mancipavit." The English translation comes from The Deeds of the Princes of the Poles, pp. 29-30.

27 M. Homza, J. Balegová (ed., trans. and comment.), Uhorsko-pol'ská kronika, pp. 150-151.

28 See: M. Homza, “14. marec roku 1074...”, passim.

29 Idem, "Včasnostredoveké dejiny Spiša”, pp. 142-143. 
relatives and "benefactors" at the very moment of assuming power in Hungary. Symptomatic is the stance of Ladislas I towards Boleslas II. The tragic king's trail, after his expulsion from Poland, is lost in Hungary. On the other hand, the "disappearance" brought about the consolidation of the Hungarian power. Boleslas II the Bold could no longer act as the most important political ally of the Papacy against the Empire in the Investiture controversy. Mightier Poland made its presence felt in the region also later, at times when Hungary was weakened for various reasons. A case in question was the mortgage on thirteen Spiš towns and Lubovňa castle in 1412. The Hungarian king Sigismund of Luxembourg was in a dire need of money that would enable him to pursue a costly foreign policy. He thus seized the opportunity after the defeat of Germanic knights and lent the aforementioned towns and the castle dominion to his brother-in-law Vladislas (Władysław) II Jagiełło for 37,000 kopas (one kopa = sixty) of Prague silver groschen. ${ }^{30}$ At that time, nobody expected that the mortgage would not be cancelled until 1769. The towns were then re-united with the rest of Spis thanks to the order of Maria Theresa. Poland - quite logically - tried to penetrate Hungarian territory through the strategically important area of northern Spiš, seeing that the Poprad is the only Slovak river flowing to the north. Poland's open interest in the area was explicitly stated for the first time in the Greater Poland Chronicle from the beginning of the $14^{\text {th }}$ century. There it took the form of a made-up story about the Spiš Burgraviate (starostwo, castellania) being the dowry of Judith, the daughter of Boleslas III, when she was going to be married to a son of Coloman the Bookish. According to the chronicle, the events took place at the beginning of the $12^{\text {th }}$ century. ${ }^{31}$ The text of the chronicle, however, was occasioned by other developments. Blessed Cunigunde, the daughter of Bela IV, the wife of Duke of Cracow, and the landlady of Sącz (from 1257), as well as Wenceslas II, the Czech and Polish king (1300-1305), did try to penetrate Hungarian territory in this area by way of donations. ${ }^{32}$ Apart from that, there were more similar Polish attempts to find ways into Hungarian territory - or modern north-eastern Slovakia - throughout history. None of them, however, proved eventually successful or managed to leave lasting effects.

Moreover, the prophecy of the anonymous Hungarian chronicler from the first third of the $13^{\text {th }}$ century can also be applied to the relations of Poland and Slovakia in the interwar period $(1918$ - 1939). The dissolution of Austria-Hungary and the subsequent political fragmentation of East-Central Europe led to the emergence of political structures similar to those of the $11^{\text {th }}$ century. On the one hand, overly self-confident Poland, and on the other, the Slovak land, this time not as a part of Hungary, but of Czecho-Slovakia. Both in the $11^{\text {th }}$ century and in the interwar period,

30 A wide literature is devoted to the mortgage on the Spiš towns. See for example: M. Suchý, "Spišské mestá v pol'skom zálohu”, in R. Marsina (ed.), Spišské mestá v stredoveku, Košice 1974, pp. 55-84; I. Chalupecký, "Snahy Uhorska o vykúpenie spišských miest z pol'ského zálohu v 15.-17. storočí”, Historické śtúdie, vol. 41 (2000), pp. 115-120.

31 MPH NS 8, ed. B. Kürbis, Warszawa 1970, p. 39.

32 See: M. Homza, "Svätá Kunigunda a Spiš", in M. Homza, R. Gładkiewicz (eds.), Terra Scepusiensis: Stav bádania o dejinách Spiša, Levoča-Wrocław 2002, pp. 381-405. 
Poland played the role of the most powerful entity in the East-Central Europe. And in both cases it failed. Belligerent tones in the relations with all its important neighbors eventually led to the demise of the Second Polish Republic in September 1939. Relations with Slovakia did not play any significant role. Although Slovakia did not possess a sufficient legal standing (over time it only gained the status of the Slovak land, Slovenská krajina, within Czechoslovakia), it did try to follow its own foreign policy. The Slavic and Catholic Poland seemed to be a natural ally for Slovakia in its situation. On the one hand, the northern neighbor formally understood and advanced Slovak efforts to achieve autonomy within Czechoslovakia (e.g. support for Hlinka on his way to the Paris peace conference in 1918, relations with K. Sidor, aid for František Hrušovský in Cracow, etc.). On the other hand, Polish attitude towards Slovakia also had its reverse side. The very same people who preached good relations with Slovakia ${ }^{33}$ and accomplished a lot in that vein, also prepared the disintegration of Czechoslovakia as well as the curtailment of the Slovak territory. This especially applies to people affiliated with the so-called Cracow center (W. Semkowicz, M. Gotkiewicz, F. Machaj, W. Goetel). The plan was supposed to follow the old saying Polak, Wegier dwa bratanki, jak do szabli, tak do szklanki (Pole and Hungarian brothers be, good for fight and good for party). ${ }^{34}$ The word Wegier was thus understood to mean a Hungarian (Magyar) in a narrower, ethnic sense, as opposed to the interpretation that would involve all members of the Hungarian nation defined politically. The aim was to eventually establish a common Polish-Hungarian border. One proposed variant was based on the historical borders of Poland on the rivers Danube and Tisza as they had been demarcated by the old Polish chroniclers. The other variant assumed the possibility of dividing the Slovak territory between the two partners, respecting the ethnic structure of the local populations. Poland "only" needed to persuade the 80,000 inhabitants of northern Slovak lands that they were actually Polish. After that, the regions of Kysuce, Orava, Tatry and Spiš could be united with Poland on the grounds of the right for national self-determination. ${ }^{35}$ As is commonly known, the development took a different path.

The events after 1918, and the Polish territorial claims against Slovakia were thus nothing new under the sun. One could actually say that whenever Poland felt strong, it always sought ways to influence the situation on the southern slopes of the Carpathians. In the autumn of 1938 , however, the annexation of the ridiculously small territories

33 As Włodysław Semkowicz writes in the Preface to Stowacja i Stowacy, vol. 2: Dzieje i literatura, W. Semkowicz (ed.), Kraków 1938: Thus, along quite a long stretch of the border, separated from us by the Carpathian mountain range, there lives a brother nation, with a language akin to ours as perhaps no other among Slavic peoples, and even closer to us in terms of character.

34 The translation used here is derived from the wiki-page devoted to the phrase at <https://en.wikipedia.org/wiki/Pole_and_Hungarian_brothers_be>, 18 November 2018.

35 On the basis of secret documents of the Polish Ministry of Interior, the two-faced nature of the policies of the Cracow center towards Slovakia was recently analyzed by: W. Czajka, "Politické aspekty v pol'sko-slovenských vztahoch v rokoch 1927-1938”, Historický časopis, vol. 35, no. 2 (1987), pp. 229-256. 
around Javorina and Suchá Hora caused outrage among a significant part of the Slovak society. It even contributed to the legitimization of the Slovak military involvement in Hitler's campaign a year later. After the subjugation of a couple of villages in Orava and Spiš that had been yielded to Poland in 1920 on the basis of a decision of the ambassadors' committee, Slovakia did not make any further requests against its northern neighbor. After WWII, the villages were ceded back to Poland.

The political situation today is identical neither to the development in the $11^{\text {th }}-12^{\text {th }}$ centuries, nor the one from the years 1918 - 1939, even though it resembles them to an extent. The main difference, however, lies in the fact that Slovakia - to the same, or even greater, extent as Poland - is nowadays dependent on its Western neighbor. Slovak-Polish relations are obviously affected by this situation, even despite the existence of Visegrad group.

\section{A FEW REFLECTIONS BY WAY OF A CONCLUSION}

There are "value-based" regimes in power in contemporary Poland and Hungary. This practically means that both countries are led by political subjects and governments that are grounded in the Christian and nationalist worldview. At the moment, the majority of political parties in the Slovak parliament, too, have been elected by an electorate that puts emphasis on these values. Unlike their Polish and Hungarian counterparts, however, the Slovak political representatives do not share the unfashionable, conservative outlook that is characteristic of the country's neighbors both to the south and north. Slovak political elites instead prefer the pragmatic (?) way of compromises. Thanks to its geopolitical position, Slovakia is once again - as so many times before - gaining the status of a decisive factor in the future development of East-Central Europe. The question that necessarily needs to be addressed now is whether Slovakia joins its neighbors and thus chooses the way that ultimately leads to the model strong : strong, or if its stance helps to definitely weaken the regional partners. There can be hardly any doubt as regards the appeal of the model strong: strong also for other countries in East-Central Europe. The dream about the creation of the fourth Roman province between the Baltic and the Adriatic (Sclavinia), and about subsequent establishment of the tetrarchy in Europe would not remain only the dream of Svätopluk I and Charles III the Fat in 884 in Tulln, or of Otto III and Bolesław the Brave in 1000 in Gniezno, or of the Hungarian and Polish king Louis the Great (1370 - 1382), or of Prince Adam Czartoryski... From this point of view, Poland - as practically the most powerful state in the region - could play an important role. The role is rooted in the historical experience, as well as in the fact that Poland shares with both Slovakia and Hungary over a millennium of peaceful coexistence. However, a third party is going to decide if the situation eventually evolves this way. As it was always the case before. 


\section{BIBLIOGRAPHY}

Bowlus Ch.R., Franks, Moravians, Magyars: the Struggle for the Middle Danube, Philadelphia 1995.

Czajka W., "Politické aspekty v pol'sko-slovenských vztahoch v rokoch 1927-1938”, Historický ćasopis, vol. 35, no 2 (1987).

Duchoňová D., Duchoň, M, “Spiš v rokoch 1711-1769”, in M. Homza, S.A. Sroka (eds.), Historia Scepusii, vol. 2: Dejiny Spiša od roku 1526 do roku 1918, Bratislava-Cracow 2016.

Galli Anonymi Cronicae et Gesta Ducum sive Principum Polonorum, in C. Maleciński (ed.), Monumenta Poloniae Historica: Nova series, vol. 2, Cracow 1952.

Homza M., Balegová J. (ed., trans. and comment.), Uhorsko-pol'ská kronika: Nedocenený prameñ $k$ dejinám strednej Európy, Bratislava 2009.

Homza M., "14. marec roku 1074 a jeho dôsledky na vývoj Nitrianskeho kniežatstva”, in R. Letz (ed.) Slovenské územie, Martin 2017.

Homza M., "La Grande Moravia tra Oriente e Occidente”, in E. Hrabovec, P. Piatti, R. Tolomeo (eds.), I Santi Cirillo e Metodio e la loro eredità religiosa e culturale ponte tra Oriente e Occidente: Raccolta di studi in occasione del $1150^{\circ}$ anniversario della missione dei santi Cirillo e Metodio nella Grande Moravia (863-2013), Città del Vaticano 2015.

Homza M., "Svätá Kunigunda a Spiš", in R. Gładkiewicz, M. Homza, M. (eds.), Terra Scepusiensis: Stav bádania o dejinách Spiša, Levoča-Wrocław 2002, 381-405.

Homza M., "Včasnostredoveké dejiny Spiša”, in M. Homza, S.A. Sroka (eds.), Historia Scepusii, vol. 1: Dejiny Spiša do roku 1526, Bratislava-Cracow 2009.

Chalupecký I., "Snahy Uhorska o vykúpenie spišských miest z pol'ského zálohu v 15.-17. storoči”, Historické štúdie, vol. 41 (2000).

Kłoczowski J. (ed.), Central Europe Between East and West, Lublin 2005.

Knoll W.P., Schaer F. (eds.), Gesta Principis Polonorum: The Deeds of the Princes of the Poles, Budapest 2003.

Kuzmová S., Preaching Saint Stanislaus: Medieval Sermons on Saint Stanislaus of Cracow: His Image and Cult, Warszawa 2012.

Labuda G., "Ze stosunków polsko-węgierskich w drugiej połowie X wieku”, in J. Bardach, et al. (eds.), Europa - Stowiańszczyzna - Polska: Studia ku uczczeniu profesora Kazimierza Tynieckiego, Poznań 1970.

Magistri Vincentii dicti Kadlubek, “Chronica Polonorum”, in M. Plezia (ed.), Monumenta Poloniae Historica: Nova Series, vol. 11, Cracow 1994.

Malinovská N., “«Regnum Sclavorum» Svjatopolka kak istočnik srednevekovych slavjanskich koncepcii Sklavinii”, in Studia Slavica et Balcanica Petropolitana, vol. 21, no. 1 (2017).

Marsina R. (ed.), Codex diplomaticus et epistolaris Slovaciae, vol. 1, Bratislava 1974.

Najstarszy zwód prawa polskiego: Das äleste Gewohnheitsrechtsbuch, (ed. and trans.) J. Matuszewski, J. Matuszewski, Łódź 1995.

Rácz G. (ed.), Visegrád 1335, Bratislava 2009.

Semkowicz W. (ed.), Słowacja i Słowacy, vol. 2: Dzieje i literatura, Cracow 1938.

Suchý M., "Spišské mestá v pol'skom zálohu”, in R. Marsina (ed.), Spišské mestá v stredoveku, Košice 1974. 
Szczur S., Historia Polski: Średniowiecze, Cracow 2002.

Szücs J., "Theoretical Elements in Master Simon of Kéza’s Gesta Hungarorum (1282-1285) ”, in

Simon of Kéza, The Deeds of the Hungarians, L. Veszprémy (ed.), F. Schaer (trans.), Budapest 1999, XXIX-CII.

Třeštík D., Vznik Velké Moravy, Praha 2010.

Wyrozumski J., Królowa Jadwiga: Między epoka piastowską i jagiellońską, Cracow 1997.

Martin HOMZA (Department of Slovak history, Faculty of Arts, Comenius University Bratislava, Slovakia) is a specialist in the field of older Slovak and Central European history. He works mainly with medieval sources of narrative character (chronicles, annales, hagiographic texts). He is the author of 7 scientific monographs and editor of comprehensive history of Spiš. In 2016 together with prof. Stanislaw A. Srokom edited the second volume Historia Scepusii: History of Spiš from 1526 to 1918. In 2017, Mulieres suadentes - persuasive women, in the Brill, prestigious Dutch publishing house. In 2005, he won the prestigious Award of Waclaw Felczak and Henryk Wereszycki given by the Jagellonian University of Krakow for book Terra Scepusiensis: The State of Research on the History of Spis. In 2012, the Polish President awarded him the Knight's Order for Merit for the Republic of Poland. He is a researcher of numerous domestic and international grants. In 2017 he received and leads the APVV grant „Slovacika from the former Kingdom of Hungary on the example of Upper Hungary (1500-1780)“. $\mathrm{He}$ is the head of the Department of Slovak history, head of Slovak-Croatian Comitee of the Human Sciences and secretary Slovak-Polish Comitee of the Human Sciences. 